\title{
A Comparative Study on Various Strength Parameters of Solid Concrete Blocks, Solid Concrete Blocks with Fly Ash and Hollow Concrete Blocks
}

\author{
${ }^{1}$ Shalini Kashyap, ${ }^{2}$ Shubhranshu Jaiswal \\ ${ }^{1}$ Post Graduate Student, Structural Engineering, ${ }^{2}$ Assistant Professor, Dept. of Civil Engg, Babu \\ Banarasi Das University, Lucknow, Uttar Pradesh, India.
}

\begin{abstract}
The article discusses the various strength parameters of conventional bricks, solid concrete blocks, solid concrete blocks with fly ash and hollow concrete blocks. Due to growing population, the demand for conventional bricks too increased so we invent various alternatives for the construction of wall. Because of different strength parameters, we find alternatives such as solid concrete blocks, solid concrete blocks with fly ash and hollow concrete blocks that should be used for present construction work. The use of concrete masonry units for high rise load-bearing construction has created a need for concrete blocks with high compressive strength.
\end{abstract}

KEYWORDS - Compressive Strength, Solid Concrete Blocks, Ecofriendly, Construction, Dry Density, Water Absorption, Sound Insulation, Thermal Conductivity.

\section{INTRODUCTION}

Bricks are the building blocks of the walls. The strength and durability of the wall depending upon the bricks. Conventional bricks are the oldest and the most common type of brick used. The popularity of conventional bricks can be attributed to its easy availability, durability, low cost, convenience, and feasibility. Due to growing population, the demand for conventional bricks too increased. Because of the increase in demand for red bricks the fertile land use for making red bricks. That's why to balance the demand and supplies of bricks, an alternative solution for bricks was researched. This has led to the use of concrete blocks as an alternative material. There are various types of cement blocks available in the market. However the most used are solid concrete blocks, solid concrete blocks with fly ash and hollow concrete blocks with fly ash. Fly ash a byproduct of industries is used in the manufacturing of concrete blocks making it eco-friendly materials. fly ash disposal was a headache and such options have made its use more beneficial to the environment. It is a revolutionary material offering a unique combination of high strength and durability, low weight and superior ecological 'Green' features. Here we discuss. about solid concrete blocks, solid concrete blocks with fly ash and hollow concrete blocks are as follows:

1.1. Solid concrete blocks: - Solid concrete blocks are commonly used in construction, which is heavy and dense aggregate manufacturing. They are very strong and provide structures with good stability and durability. Thus these solid blocks are preferable for large masonry work as for load-bearing walls. They come in large sizes and various dimensions as compared to conventional bricks. So the construction of concrete masonry takes less time than conventional brick masonry.

1.2. Solid concrete blocks with fly ash: - Fly ash is produced by burning pulverized coal in electric generating power plants. Fly ash is a substance containing aluminous and siliceous material that forms cementitious material in the presence of water. When we mixed fly ash in lime and water, fly ash forms a compound that is similar to Ordinary Portland cement. That why fly ash suitable as a prime material in blended cement, mosaic tiles, and hollow blocks, among other building materials. When we used fly ash in concrete mixes, fly ash improves the strength and segregation of the concrete. Solid concrete blocks with fly ash reduce dead load on structure due to lightweight, provide high fire resistance, due to high strength no damage during transportation and use, due to uniform size of solid concrete blocks mortar required for joint and plaster reduces up to $50 \%$ and these blocks do not require 24 hours curing, Only we use sprinkling of water before construction work.

1.3. Hollow concrete blocks:-Hollow blocks of concrete have a void area greater than $25 \%$ of the gross area. Hollow concrete blocks should have a solid area of more than $50 \%$. Based on our requirement as per site construction, the hollow part of concrete block may be divided into several components. They are made from lightweight aggregates. They are light in weight and easy to the construction of the wall in high rise buildings. 


\section{OBJECTIVE}

The main objective of this review paper is to comparison among solid concrete blocks, solid concrete blocks with fly ash and hollow concrete blocks. And also study the effect of fly ash on concrete blocks with its various parameters.

\section{LITERATURE REVIEWS}

Ravi Kumar, Deepankar Kumar Ashish (March 2014) studied the Properties of lightweight fly ash Brick. In this paper we research fly ash blocks conduct within different proportions of fly ash, cement, lime, gypsum, and sand. The experimental shows that the compressive strength of fly ash brick at 5 percent cement replacement is $152 \mathrm{~kg} / \mathrm{cm} 2$ which is approximately 40 percent more than class 1 st traditional brick.

\section{Panuwat Joyklad, Nazam Ali, Qadeer Hussain (August} 2018) they are prepared paper name was "Performance of hollow brick made of fly ash, cement, and sand". In this study, different techniques were used to improve the mechanical properties of CCI bricks. Sand, cement and fly ash were used to develop new mix designs. Results showed a marked increase in the compressive strength of the newly manufactured CCI brick as compared with the original bricks. Other mechanical properties including the water absorption and modulus of rupture of the newly manufactured CCI hollow bricks also improved.

Vinay Kumar Abhijith M. Arer, Sangeetha B.K., Sweta C. Patil, Suma U. Pateela (May 2018) studied the cement concrete hollow block to replacing cement by fly ash. In this study, an effort of $0 \%, 10 \%, 20 \%, 30 \%$, and $40 \%$ of fly ash for concrete grade M30 on the compressive strength of concrete by partial substitution of cement. He found that concrete workability and durability improve with increased fly ash content. When we increase the percentage of fly ash the concrete's compressive strength decreased. Around 30 percent replacement of cement with fly ash, the optimal result is obtained

A. A. Raheem, O. K. Sulaiman (January 2013) this study investigates the use of Sawdust ash as a partial replacement for cement in the production of concrete hollow blocks. This study investigates the use of Sawdust as a partial replacement of cement in concrete blocks. The result indicated that compressive strength of concrete hollow blocks at 28 days are $2.16 \mathrm{~N} / \mathrm{mm}^{2}, 1.94 \mathrm{~N} / \mathrm{mm}^{2}, 1.64$ $\mathrm{N} / \mathrm{mm}^{2}, 1.59 \mathrm{~N} / \mathrm{mm}^{2}, 1.39 \mathrm{~N} / \mathrm{mm}^{2}$ and $1.25 \mathrm{~N} / \mathrm{mm}^{2}$ at $5 \%$, $10 \%, 15 \%, 20 \%$ and $25 \%$ Sawdust ash content replacement with cement.

Prakash T. M. Examine the possibility of using the lightweight concrete block as an alternative to traditional masonry systems. The preliminary studies focused on estimating the physical and elastic properties of lightweight units in cellular blocks. These included initial absorption rate, density test, water uptake test, etc. The compressive strength, the features of tension and Flexural strength was obtained for the units. And the tests equate to those of traditional masonry units.

P.S. Bhandari Investigate the behavior of lightweight cellular concrete concerning density and compressive strength. Cellular lightweight concrete's Compressive strength is low for lower density mixture. Cellular lightweight concrete's compressive strength decreases with increase of voids. The 53-degree Compressive strength of ordinary Portland cement is more than 43 degrees of ordinary Portland cement because strength also increases its density. For framed construction cellular lightweight concrete is appropriate. The lightweight cellular concrete may be suitable for areas prone to earthquakes.

Chaure A.P. has been Studies on the construction of hollow concrete block masonry underlining in the present. This study also discussed the crack pattern developed in the structural elements such as wall. The strength of the wall constructed with a hollow concrete block gives less strength as compared to brick masonry but the cost of construction reduced.

Sittati Musalamah analyzed the "comparative study on the proportion of hollow concrete block to its compressive strength". This paper will do a comparative study on the proportion of hollow concrete blocks to help the producer, researcher, and public to get the target strength easily based on the determination of fine aggregate quality and watercement ratio. The proportion of cement and fine aggregate was selected to be $1: 1$ to $1: 6$ and 0.5 for the water-cement ratio.

Frasson Jr. studied "A mix design methodology". In this paper, he presented a mix design procedure for structural concrete block based on laboratory test. In this initially, a reference mixer is studied. In this phase, it is possible to vary the type and proportion of aggregates, admixtures and water content to achieve a suitable face texture with a lower energy of compaction. After that several mixtures are produced varying the cement content and density.

R. Sayanthan described the "Development of interlocking lightweight cement blocks". The interlocking hollow blocks developed are $600 \mathrm{~mm} * 200 \mathrm{~mm} * 200 \mathrm{~mm}$ in size with a weight of $20 \mathrm{~kg}$. The expanded polystyrene beads have been used to reduce the self-weight. Experimental investigation has shown that the average compressive strength of block was $4.91 \mathrm{~N} / \mathrm{mm} 2$, Therefore is can be used for load-bearing masonry walls. It was also observed ductile load-deformation behavior at the failure of the masonry wall panel, which is an added advantage.

Lalit Krishna Nayak studied the "structural behavior of concrete block with fly ash content and waste rubber as its loading surface for industrial purpose". This paper presents the results of a series of tests conducted to assess the influence of block shape, thickness, size, the compressive 
strength of the concrete block. It is emphasized on optimum use of waste materials generated from thermal plants and vehicles amalgamating it with proper ratio with concrete material that would generate a desired new material that satisfies the customer needs.

\section{MATERIAL}

3.1.1. Cement: - Cement is a substance used for concrete material that sets, hardens, and adheres to other materials to bind them together. Cement mixed with sand and gravel produces concrete. For cementitious binders, water is mixed with the dry powder and aggregate, which produces a semiliquid slurry that can be shaped, typically by pouring it into a form. The concrete solidifies and hardens through a chemical process called hydration. The water reacts with the cement, which bonds the other components together, creating a robust stone-like material.
3.1.2. Aggregates: - The aggregates used in the manufacture of blocks at the mixer or the mixing platform shall be clean and free from deleterious matter. Both gravel and crushed stone are generally acceptable for making good quality concrete.

3.1.3. Water: - The water used in the manufacture of concrete blocks shall be free from harmful ingredients to concrete or reinforcement because it causes efflorescence in the blocks.

3.1.4. Fly ash: Fly ash is a fine powder formed by the power plant. For Portland cement concrete manufacture this is a supplementary cement material. When used with Portland cement, a supplementary cement content improves the properties of the hardened concrete by hydraulic or pozzolanic action.

\section{CONCLUSION}

Table No. 1. The various parameters of conventional bricks, solid concrete blocks, solid concrete blocks with fly ash and hollow concrete block are as follows:

\begin{tabular}{|c|c|c|c|c|}
\hline PARAMETERS & CONVENTIONAL BRICKS & $\begin{array}{l}\text { SOLID CONCRETE } \\
\text { BLOCKS }\end{array}$ & $\begin{array}{ll}\text { SOLID } & \text { CONCRETE } \\
\text { BLOCKS } & \text { WITH FLY } \\
\text { ASH } & \end{array}$ & $\begin{array}{l}\text { HOLLOW } \\
\text { CONCRETE BLOCKS }\end{array}$ \\
\hline Raw materials & $\begin{array}{l}\text { Lime clay or alumina, sand, iron } \\
\text { oxide, magnesia }\end{array}$ & OPC, sand, gravel, water & $\begin{array}{l}\text { OPC, sand, gravel, water, } \\
\text { fly ash }\end{array}$ & OPC, sand, gravel, water \\
\hline Compressive Strength & 3.5 to $7.5 \mathrm{~N} / \mathrm{mm}^{2}$ & 5 to $7.5 \mathrm{~N} / \mathrm{mm}^{2}$ & $\begin{array}{l}2.8 \text { to } 10.5 \mathrm{~N} / \mathrm{mm}^{2} \\
\text { (Avg.) at } 10 \% \text { fly ash }\end{array}$ & 2.8 to $10 \mathrm{~N} / \mathrm{mm}^{2}$ \\
\hline Dry density & 1600 to $1920 \mathrm{~kg} / \mathrm{m}^{3}$ & 1800 to $2500 \mathrm{~kg} / \mathrm{m}^{3}$ & 1700 to $1850 \mathrm{~kg} / \mathrm{m}^{3 \mathrm{~s}}$ & 800 to $1800 \mathrm{~kg} / \mathrm{m}^{3}$ \\
\hline $\begin{array}{l}\text { Water Absorption of its } \\
\text { weight }\end{array}$ & Not more than $20 \%$ & Not more than $10 \%$ & Not more than 15 to $20 \%$ & $\begin{array}{l}\text { Not more than } 7.5 \text { to } \\
12.5 \%\end{array}$ \\
\hline Thermal conductivity & 0.6 to $1.0 \mathrm{~W} / \mathrm{m} \mathrm{K}$ & 0.7 to $1.28 \mathrm{~W} / \mathrm{m} \mathrm{K}$ & 0.3 to $0.4 \mathrm{~W} / \mathrm{m} \mathrm{K}$ & 0.32 to $0.54 \mathrm{~W} / \mathrm{m} \mathrm{K}$ \\
\hline Sound Insulation & $\begin{array}{l}45 \mathrm{~dB} \text { sound is reduced by } 150 \mathrm{~mm} \\
\text { and } 50 \mathrm{~dB} \text { sound is reduced by } 230 \\
\mathrm{~mm} \text { thick walls. }\end{array}$ & $\begin{array}{l}51 \mathrm{~dB} \text { sound is reduced } \\
\text { by a } 150 \mathrm{~mm} \text { thick wall } \\
\text { of solid concrete blocks. }\end{array}$ & $\begin{array}{l}37 \text { to } 39 \mathrm{~dB} \text { sound is } \\
\text { reduced by } 100 \mathrm{~mm} \text { thick } \\
\text { wall of fly ash concrete } \\
\text { blocks. }\end{array}$ & $\begin{array}{l}37 \text { to } 42 \text { dB sound is } \\
\text { reduced by hollow } \\
\text { concrete blocks. }\end{array}$ \\
\hline
\end{tabular}

The comparison of a conventional brick, solid concrete blocks, solid concrete blocks with fly ash and hollow concrete blocks will help you in the selection of concrete blocks for the construction of the wall in high rise buildings. Conventional bricks are made from natural soil and are used continuously for construction that's why the time will come when natural resources to be reduced. Because of this reason various alternatives such as solid concrete blocks, solid concrete blocks with fly ash and hollow concrete blocks should be used for the construction of high rise buildings. Because of various strength parameters, we use different types of concrete blocks as per the requirement of need at the construction site.

\section{ACKNOWLEDGMENT}

We would like to express our sincere thank towards researchers who gives us valuable information which is useful in the proposed project. I wish to express my deepest gratitude and indebtedness to my supervisors, $\mathrm{Mr}$.
Shubhranshu Jaiswal for their stimulating ideas, numerous constructive suggestions and guidance, continuous encouragement and invaluable support throughout this study. Without their advice, encouragement, and support, this thesis would not be completed.

\section{REFERENCES}

[1]. Concrete masonry unit-Specification (Part-1) 2005.

[2]. Pulverized Fuel Ash - Specification (Part-1) 2013.

[ 3].Bronius Jonaitis, Robertas Zavalis, "Experimental Research o n Hollow Beton Block Stress Deformations," 11th International C onference on Modern Building Materials, Structures and Technolo gies, MBMST 2013.

[4].Prof. Omprekash Netula, Shailendra Pal Singh, Er. Rohan Bhomia, International Journal of Technology Science and Research (IJETSR) - Vol.4, No.12, December 2017

[5]. Vinay Kumar, S.R.Abhijith M.Arer, Sangeetha B.K., Suma.U.Pateela, Sweta.C.Patil, IRJET Journal, Vol.5, May 2018. 
[6].Frasson Jr., Artemio, Casali, Juliana Machado, Oliveira, Alexandre Lima, Prudencio Jr., Luiz Roberto,15 International Brick, and Block Masonry Conference, Brazil 2012.

[7].Chaure A. P, Shinde P.A, Raut H.M, Dudhal P. D, Khotkar R.G, "Hollow Concrete Block", IJARIIE Journal, Vol.4,2018.

[8].Hrituraj Singh Rathore, Dr. Savita Maru," comparative study of AAC block and brick fully infill building and building having a soft-story at different floors subjected to the earthquake", IJRASET Journal, Vol.6, March 2018.

[9].A.A.Raheem and O.K.Sulaiman, "sawdust ash as a partial replacement for cement in the Production of sandcrete hollow blocks", IJERA Journal, Vol.3, Jul-Aug2013.

[10]. Mr. Sagar Wankhede, Mr. Suraj Mehetre, Mrs. Priyanka Katkar, Mrs. Nayana Ganneshkar "Comparative Analysis of G+10 RCC Building with Conventional Blocks and AAC Blocks" IJRAT Journal,09 April 2018.

[11]. R. Sayanthan, S. Ilamaran, Mohd. Rifdy and S.M.A.Nanayakkara, $4^{\text {th }}$ international conference on structural Engineering and Construction Management 2013, Kandy, Sri Lanka,13,14, and 15 December 2013.

[12]. ACI Committee 531, "Building code Requirements for Concrete Masonry Structures", ACI Journal, Proceedings V.75, No.8, p. 384-403, Aug. 1978.

[13]. Curtin, W. G., Shaw, G., Beck, J. K. and Parkinson, G. I., "Structural Masonry Detailing", Granada Publishing Limited, London, 1989.

[ 14 ] Mehta P. K, Duggal S, Abhishek Kumar, K, Tabin Rushad S , Lime-Soil-Fly Ash Bricks Experimental Studies, International Journal of Civil and Structural Engineering. Vol.1, No.4, 2011 [ 15 ] Prof. Jayeshkumar Pitroda, Nutan C. Patel, Fly Ash Brick: Glass Fiber Innovative Design for Higher Strength Brick. International Journal of Innovative Research in Science, Engineering and Technology, Vol. 2, Issue 3, March 2013

[16] A.Sumathi, K.Saravana Raja Mohan, Fly Ash Bricks Compressive Strength. IJCRGGISSN: 0974-4290 Vol.7, No.01, pp 28-36.2014-2015

[17] H N Rajendra Prasad1, H. G. Vivek Prasad2, D Yogesh Gowda, Sree Pushpak Gowda U S6, An Approach For. Alternative Brick Manufacturing Solution. ISSN 2278-3687(O) and Technology Journal of Science, Environment, Vol. 3, 2014, No 3, 1105-1114.

[ 18 ] Hashim K Abdul Azeez3, Nesiya Yoosaf1, Remya Raju2, C omparative Study of Multi-story RC Building Having Different Type Infill Walls with Open Ground Storey. International Journal of Trends and Technology in Engineering (IJETT)-Vol.28,

No.7, October 2015

[ 19] Aakash Suresh Pawar, International Journal of Engineering and Technology Research, Properties engineering of clay bricks us ing fly ash. No. Vol. 2, 04.2014 No.

[20] Thanikalapradeep1, Selvakumar Viswanathan, Sinthiya Rav i, V.Srinivas and Premavathi Narayana, Experimental Approach to Investigate the Different Mortar Ratio Conduct of Brick Masonry. Intra-national Conference on Engineering and Technology Advancement (Icat'2014) 30 March 2014

[21]. Panuwat Joyklad, Nazam Ali and Qudeer Hussain,
"Performance of hollow brick made of fly ash, cement, and Sand".

[ 22 ]. Ravi Kumar, Vandana Patyal, Balwinder Lallotra, and Deepankar Kumar, International Journal of Engineering Research and Application ISSN-9622(AET-29 March 2014), "study of the properties of lightweight fly ash brick" [23]. Parul, R. Patel, "Brick Manufacturing Use of Fly Ash," National C onference on Advances in Building Materials, "AICM-

India, 2004, 53-56.

[ 23 ]. Peter George Kenneth Kingth," Pulverized ash from fuel as a building material, "Civil Engineers institution proceedings, 16, 1960, 419-432.

[25]. Butterworth B., "Fire Ash made from pulverized bricks.", Trans. Brit. Brit. Ceram. Ceram. Soc ' ENGLAND, 293-313, 1954 [26]. Gupta Sen J., "Fly Ash Availability and its Construction Industry Application," NBO Journal, 1984, 17-22.

[ 27 ] Thorne, D.L., Watt, J.D., "Composition of pulverized fuel as $\mathrm{h}$ and its properties.

[28] Hendry, A. W., Fairbairn, R. D., \& Khalaf, M. F., 1992. Mechanical properties of materials used for the construction of concrete blockwork, Magazine of Concrete Science 44(158), p. 1.

[29] Khalaf, F. M., 1996. Factors influencing compressive strength of concrete masonry prisms, Magazine of Concrete Research 48(175), p. 95.

[30] Köksal, H. O., Karakoç, C., \& Yildirim, H., 2005. Compression Behavior and Failure Mechanisms of Concrete Masonry Prisms, Journal of Materials in Civil Engineering 17(1), p. 107.

[31] Mohamad, G., Lourenço, P. B., \& Roman, H. R., 2007 Mechanics under compression of hollow concrete block masonry prisms: review and prospects.Cement and Concrete Composites 29(3), p. 181.

[32] Steadman, M., Drysdale, R. G., \& Khattab, M. M., 1995. "Influence of block geometry and form of grout on Block Masonr $y$ 's compressive strength. "Proceedings of the 7th Symposium on Canadian Masonry, pp. 1116-1127.

[33] LST EN 1996-1-1 Eurocode 6: Masonry Structures DesignPart 1-

1: Reinforced and Unreinforced Masonry Regulations, 2005.

[34] LST EN 1052-1 Methods of test for Masonry - Part 1: Determination of compressive strength, 1999. [38] LST EN 772-1 Methods of tests for masonry units - Part 1: Determination of compressive strength, 2011.

[35] LST EN 1015-11 Methods of mortar testing for masonry Part 11: Flexure determination and compressive strength of hardened mortar, 1999.

[36] LST EN 12390-3 Testing hardened concrete - part 3: Compressive strength of test specimens, 2011. 